\title{
Pelatihan Self-Control For Pupils (Stop) untuk Meningkatkan Kontrol diri Siswa SMP
}

\author{
Yudhistira Adi Perdana ${ }^{1}$, Amitya Kumara², E Diana Setiyawati ${ }^{3}$ \\ Fakultas Psikologi Universitas Gadjah Mada;
}

\begin{abstract}
Teenagers are in period of transition toward adulthood. At that time, adolescents experienced various changes in his life. Teenagers are at risk of experiencing various problems. Characteristics of these teenagers make it requires a skill in coping with the problem. Self-control is one of the most important factors in adolescent life. Self-control has two main components, namely emotion expression and adaptive behavior. Self-control can be improved with training. This study aimed to determine the effect of Self-control for Pupils (STOP) training on self-control of junior high school students. Student self-control was measured using self-control scale. The participants in this study were eight people of Junior High School who became experimental groups. The results of paired sample t-test indicated that Self-control for Pupils (STOP) training did not significantly affect student self-control $(t=$ $-1.158 ; p=0.285 ; p>0.05)$.
\end{abstract}

Keyword: experimental; self-control; training

Abstrak. Remaja merupakan masa transisi menuju kedewasaan. Pada masa itu, remaja mengalami berbagai macam perubahan dalam hidupnya. Remaja berisiko mengalami berbagai macam permasalahan. Karakteristik remaja tersebut membuatnya membutuhkan suatu keterampilan dalam mengatasi permasalahannya. Kontrol diri merupakan salah satu faktor penting dalam kehidupan remaja. Kontrol diri memiliki dua komponen utama, yaitu emotion expression dan adaptive behavior. Kontrol diri dapat ditingkatkan melalui pelatihan. Penelitian ini bertujuan untuk mengetahui pengaruh pelatihan Self-control for Pupils (STOP) terhadap kontrol diri siswa SMP. Kontrol diri subjek penelitian diukur menggunakan skala kontrol diri. Subjek dalam penelitian ini adalah delapan orang siswa SMP yang menjadi kelompok eksperimen. Hasil uji paired sample t-test menunjukkan bahwa pelatihan Self-control for Pupils (STOP) tidak berpengaruh secara signifikan terhadap kontrol diri siswa SMP $(t=-$ $1,158 ; p=0,285 ; p>0,05)$.

Kata kunci: eksperimen; kontrol diri; pelatihan

Remaja merupakan masa di mana terjadi perubahan besar dalam kehidupan. Salah satu contoh perubahan besar pada remaja tersebut adalah kecenderungan remaja untuk merasakan emosi yang tidak logis atau tidak masuk akal. Remaja juga dapat

${ }^{1}$ Korespondensi dapat dilakukan melalui

yudhistira.adi.p@mail.ugm.ac.id

${ }^{2}$ Atau melalui diana@ugm.ac.id melakukan perilaku negatif sebagai wujud dari perubahan pada dirinya (Berger, 2011). Dewasa ini, dapat kita temui di berbagai pemberitaan di surat kabar mengenai tindakan remaja yang melakukan berbagai macam perilaku negatif, seperti melakukan bullying, melakukan tindakan klithih, dan lain-lain. Para remaja tersebut seharusnya melakukan kewajibannya sebagai seorang pelajar, seperti belajar, mengerjakan tugas, 
dan mengisi waktu luang dengan berbagai kegiatan positif.

Masa remaja merupakan masa kritis yang menandai peralihan dari ketidakdewasaan menuju kedewasaan (Spear, 2007). Dalam masa peralihan tersebut, tentu saja banyak masalah yang dapat terjadi pada diri remaja. Penelitian yang dilakukan oleh Hartanto dan Selina kepada remaja Sekolah Menengah Pertama (SMP) di Kota Semarang pada tahun 2011 menunjukkan hasil bahwa 9,1\% remaja SMP tersebut memiliki permasalahan mental dan emosional (Utami, 2012). Penelitian yang dilakukan oleh Nindya \& Margaretha (2012) menunjukkan bahwa kekerasan emosional pada diri remaja memiliki korelasi dengan kecenderungan kenakalan remaja.

Berbagai permasalahan dan perilaku negatif yang dilakukan para pelajar remaja itu dapat dikarenakan kurangnya keterampilan kontrol diri (Casey \& Caudle, 2013). Kurangnya kemampuan remaja dalam mengendalikan dirinya dapat memunculkan berbagai permasalahan yang tentu saja memengaruhi kehidupan remaja. Pengaruh tersebut dapat berdampak tidak hanya pada kesehatan fisiologis saja, namun juga berdampak pada kesehatan psikologis atau kesehatan mental remaja. Selain itu, kurangnya keterampilan kontrol diri dapat berdampak dalam bidang interaksi sosial. Penelitian yang dilakukan oleh Bradley \& Webb (1976; dalam Santrock, 2011) menemukan hasil bahwa pada kelompok usia 13 sampai 18 tahun, mereka menunjukkan kurangnya kontrol diri dalam bidang sosial.

Kontrol diri dapat ditemukan dalam berbagai literatur pendidikan, khususnya dalam konteks sekolah (Berger, 2011). Asumsi yang digunakan adalah pencapaian keberhasilan para pelajar tidak dapat dijelaskan oleh kemampuan dan keterampilan yang dimiliki oleh pelajar itu saja, namun ada faktor lain yang berpengaruh. Salah satu faktor tersebut adalah kontrol diri. Kontrol diri memiliki kontribusi penting dalam kesuksesan belajar siswa (Schunk, 2005).

Kontrol diri dapat dipengaruhi oleh beberapa faktor. Warry, Remington, \& Sonuga-Barke (1999) mengungkapkan bahwa ada tiga hal yang dapat mempengaruhi kontrol diri, yaitu motivasi, kognitif, dan perbandingan sosial. Ketiga faktor tersebut erat kaitannya dengan pengetahuan atau informasi mengenai hasil yang akan diperoleh berdasarkan berbagai pertimbangan. Berbagai faktor yang dapat mempengaruhi kontrol diri tersebut dapat dipengaruhi juga oleh faktor lain, seperti pelatihan. Kontrol diri dapat dilatih atau ditingkatkan melalui pelatihan (TuckerLadd, 2011). Hal ini dikarenakan kontrol diri merupakan bagian dari proses pembelajaran sepanjang hidup seseorang. Seseorang dapat meningkatkan kemampuan kontrol dirinya dengan mempelajari cara melakukan kontrol diri yang baik. Proses pembelajaran dalam pelatihan tersebut akan berpengaruh terhadap kemampuan kontrol diri seseorang (Tucker-Ladd, 2011).

Banyak peneliti telah mengembangkan program pelatihan dengan kurikulum atau kegiatan yang ditujukan untuk melatih kemampuan kontrol diri (Tarullo, Obradovic, \& Gunnar, 2009). Beberapa penelitian dengan menerapkan metode pelatihan telah dilakukan untuk menemukan pengaruh dari pelatihan tersebut terhadap kontrol diri. Pelatihan mampu meningkatkan kontrol diri siswa dalam rangka mengurangi perilaku merokok pada kategori merokok rendah dan sedang (Janah, 2004). Pelatihan kontrol diri mampu menurunkan kecenderungan kenakalan pada remaja (Rohmadani, 2011). Selain itu, pelatihan juga mampu meningkatkan pengendalian perilaku pada siswa SMP (Putri, 2014).

Penelitian ini bertujuan untuk menguji dan mengetahui pengaruh pelatihan yang dibuat oleh peneliti terhadap kontrol diri 
subjek penelitian. Pelatihan tersebut merupakan perlakuan yang diberikan kepada subjek penelitian dalam kelompok eksperimen. Penelitian ini diharapkan mampu memberikan informasi yang bermanfaat bagi peneliti selanjutnya yang tertarik dengan pelatihan dan kontrol diri.

Pengertian kontrol diri secara luas merujuk pada kemampuan untuk mengawasi dan mengatur kesadaran, emosi, dan perilaku. Kemampuan tersebut dibutuhkan untuk memenuhi tujuan maupun menyesuaikan diri. Konteks yang berlaku untuk penyesuaian diri merupakan situasi khusus/spesifik yang membutuhkan penyesuaian antara kognitif dan tuntutan sosial. Komponen utama kontrol diri adalah emotional response dan adaptive behavior (Berger, 2011).

Kontrol diri dipengaruhi oleh beberapa faktor. Menurut Warry et al., (1999), ada tiga hal yang dapat mempengaruhi kontrol diri, yaitu motivasi, kognitif, dan perbandingan sosial. Faktor motivasi berhubungan dengan risiko atau hasil yang akan diperoleh seseorang. Faktor kognitif berhubungan dengan ketersediaan informasi yang berguna dan akan berpengaruh bagi masa depannya. Faktor perbandingan sosial berhubungan dengan pengetahuan seseorang mengenai tindakan orang lain dan hasil yang diperolehnya apabila ia berada pada posisi orang tersebut.Tucker-Ladd (2011) turut menyatakan bahwa pelatihan juga merupakan faktor yang dapat berpengaruh terhadap kontrol diri. Kontrol diri merupakan bagian dari hasil belajar berdasarkan pengalaman. Inti dari perubahan pada diri seseorang adalah karena adanya pembelajaran. Pembelajaran tersebut berlangsung sejak lahir sampai saat meninggal nanti. Perilaku yang telah menjadi kebiasaan kita sehari-hari juga merupakan hasil dari pembelajaran tersebut, begitu juga dengan cara seseorang dalam melakukan kontrol diri. Oleh karena itu, perubahan tersebut dapat dilakukan dengan cara berlatih. Peneliti mengajukan hipotesis bahwa pelatihan yang dibuat oleh peneliti memiliki pengaruh terhadap kontrol diri subjek penelitian.

\section{Metode}

Penelitian ini merupakan penelitian eksperimen. Penelitian ini mengunakan pendekatan kuantitatif eksperimen one group pretest-posttest design. Desain penelitian eksperimen ini hanya menggunakan kelompok eksperimen tanpa disertai dengan kelompok kontrol. Desain eksperimen ini biasanya diterapkan untuk sebuah pilot study, yaitu penelitian eksperimen dengan jumlah subjek yang sedikit (Christensen, 2004). Rancangan eksperimen yang digunakan dapat dilihat pada Gambar 1.

Eksperimen ini dilakukan secara klasikal, artinya semua subjek mendapatkan perlakuan yang sama pada saat bersamaan. Desain eksperimen one group pretest-posttest memungkinkan peneliti untuk mengetahui perbedaan skor yang diperoleh subjek pada saat prestest dan posttest. Data hasil pretest dan posttest subjek penelitian dalam kelompok eksperimen selanjutnya dianalisis untuk mengetahui pengaruh perlakuan terhadap perubahan skor dari pretest ke posttest. Skor pretest dan posttest yang dimaksud adalah skor kontrol diri subjek penelitian yang diukur menggunakan skala.

Perlakuan yang diberikan dalam eksperimen ini adalah pemberian pelatihan kepada kelompok eksperimen. Peneliti menyusun modul pelatihan yang didasarkan pada teori kontrol diri menurut Berger (2011) dan juga panduan penyusunan modul menurut Russel \& Johanningsmeier (1981) serta Supratiknya (2011). Modul pelatihan tersebut diuji validitas isi terlebih dahulu melalui expert judgment. Pelatihan ini diberi nama pelatihan Self-control for Pupils (STOP). Nama "STOP" dipilih untuk mengingatkan orang dengan rambu-rambu peringatan. Hal ini dimaksudkan agar 


\section{$\mathrm{O}_{1} \quad \mathrm{X} \quad \mathrm{O}_{2}$}

Gambar 1. Rancangan Eksperimen

Keterangan:

$\mathrm{O}_{1} \quad$ : Pengukuran pertama (pretest)

$\mathrm{X}$ : Perlakuan

$\mathrm{O}_{2} \quad$ : Pengukuran kedua (posttest)

peserta pelatihan dapat teringat dengan kontrol diri setiap kali menanggapi suatu situasi di kehidupan nyata.

Subjek dalam penelitian ini adalah remaja yang memenuhi kriteria subjek penelitian. Kriteria subjek dalam penelitian ini, yaitu: 1) Siswa/i Sekolah Menengah Pertama (SMP) kelas VII atau VIII di Yogyakarta; 2) Bersedia mengikuti keseluruhan proses dalam pelatihan. Teknik pengambilan subjek yang digunakan dalam penelitian ini adalah teknik purposive sampling, di mana peneliti menentukan partisipan untuk menjadi subjek penelitian berdasarkan kesesuaian dengan kriteria yang dibuat. Purposive sampling digunakan untuk menemukan partisipan yang memenuhi kriteria dan bersedia memberikan informasi yang dimiliki berdasarkan pengetahuan dan/atau pengalaman (Etikan, Musa, \& Alkassim, 2016). Dalam penelitian ini, diperoleh delapan orang subjek penelitian yang tergabung dalam kelompok eksperimen.

Pengumpulan data dalam penelitian ini menggunakan skala psikologi, observasi, dan evaluasi pelatihan. Skala psikologi yang digunakan dalam penelitian ini adalah skala kontrol diri yang ditujukan untuk mengukur skor kontrol diri subjek penelitian. Skala kontrol diri ini dikembangkan oleh Kumara, Wimbarti, Susetyo, \& Widhiarso (2016). Aspek-aspek yang diukur yaitu emotion expression dan adaptive social behavior. Skala ini terdiri dari 10 aitem.

Alternatif respons yang tersedia dalam skala ini menggunakan model summated scale dengan empat pilihan jawaban. Pilihan jawaban yang tersedia yaitu Tidak Pernah, Jarang, Kadang-kadang, dan Sering. Skor untuk masing-masing pilihan jawaban yaitu Tidak Pernah = 4; Jarang = 3; Kadang-kadang $=2$; dan Sering $=1$. Khusus untuk aitem nomor 6 menggunakan kriteria penilaian berbeda, yaitu Tidak Pernah $=1$; Jarang $=2$; Kadang-kadang $=3$; dan Sering $=4$. Hal ini dikarenakan aitem nomor 6 merupakan satu-satunya aitem unfavorable. Konsistensi internal (reliabilitas) dari skala kontrol diri ini memiliki nilai koefisien Alpha Cronbach 0,719. Nilai koefisien Alpha di atas 0,70 dapat dikatakan baik.

Penelitian ini diawali dengan menentukan topik utama penelitian. Tahap persiapan penelitian juga meliputi studi kepustakaan dengan mencari sumber yang terkait dengan topik penelitian. Peneliti dalam penelitian ini menyusun modul pelatihan yang akan dijadikan sebagai pedoman pelaksanaan pelatihan Self-control for Pupils (STOP) selaku bentuk perlakuan dalam eksperimen. Modul Pelatihan Selfcontrol for Pupils (STOP) selanjutnya diberikan kepada experts untuk diberikan professional judgment dalam rangka validasi isi modul. Peneliti selanjutnya melakukan perizinan penelitian. Selanjutnya, pelaksanaan eksperimen dilakukan pada kelompok eksperimen dalam satu kali pertemuan dengan durasi kurang lebih tiga jam. Peneliti mengukur skor kontrol diri subjek penelitian melalui pretest dan posttest. Peneliti selanjutnya melakukan uji statistik pada data yang berhasil dikumpulkan untuk menguji hipotesis. Tahap berikutnya adalah membuat kesimpulan berdasarkan analisis data.

Data yang diperoleh dalam penelitian ini dianalisis dengan menggunakan uji paired sample t-test. Paired sample t-test digunakan untuk melihat perbandingan skor pretest dan posttest pada kelompok subjek yang sama, yaitu skor pretest dan posttest kelompok eksperimen. Apabila nilai probabilitas atau 
Tabel 1.

Hasil Penelitian

\begin{tabular}{ccccc}
\hline \multirow{2}{*}{ Subjek } & \multicolumn{2}{c}{ Skor Kontrol Diri } & Perubahan & Keterangan \\
\cline { 2 - 3 } & Pretest & Posttest & Skor & Menurun \\
\hline SMP-1 & 27 & 26 & -1 & Tetap \\
SMP-2 & 28 & 28 & 0 & Tetap \\
SMP-3 & 32 & 32 & 0 & Meningkat \\
SMP-4 & 27 & 28 & +1 & Tetap \\
SMP-5 & 32 & 32 & 0 & Meningkat \\
SMP-6 & 31 & 32 & +1 & Meningkat \\
SMP-7 & 19 & 21 & +2 & Tetap \\
SMP-8 & 38 & 38 & 0 & \\
\hline
\end{tabular}

Sig. (2-tailed) $<0,05$ maka terdapat perbedaan yang signifikan pada pretest dan posttest, artinya adalah ada pengaruh dari perlakuan terhadap variabel dependen. Sebaliknya, apabila Sig. (2tailed) $>0,05$ maka tidak terdapat perbedaan yang signifikan pada pretest dan posttest yang dapat diartikan bahwa tidak ada pengaruh dari perlakuan terhadap variabel dependen.

\section{Hasil}

Hasil validasi isi modul pelatihan Selfcontrol for Pupils (STOP) memiliki koefisien validitas isi yang bergerak dari 0,6-0,95. Hasil tersebut menunjukkan bahwa modul pelatihan Self-control for Pupils (STOP) memiliki validitas isi yang cukup baik. Hasil analisis uji reliabilitas skala kontrol diri menghasilkan nilai koefisien alpha cronbach sebesar 0,720. Dengan demikian, dapat dinyatakan bahwa skala kontrol diri dalam penelitian ini memiliki reliabilitas yang baik.

Data utama dalam penelitian ini adalah skor kontrol diri subjek yang diukur menggunakan skala kontrol diri.. Masing-masing subjek penelitian memiliki skor kontrol diri untuk pretest dan posttest.
Selanjutnya, peneliti melakukan uji hipotesis menggunakan uji paired sample ttest. Uji paired sample t-test digunakan untuk mengetahui perbedaan skor kontrol diri subjek sebelum dan sesudah diberikan perlakuan berupa pelatihan Self-control for Pupils (STOP).

Berdasarkan analisis data yang dilakukan, hasil uji paired sample t-test menunjukkan tidak adanya perbedaan skor kontrol diri yang signifikan pada kelompok eksperimen $(t=-1,158 ; p=0,285$; $p>0,05)$. Hipotesis yang diajukan dalam penelitian ini ditolak. Dengan demikian, dapat diambil kesimpulan bahwa pelatihan Self-control for Pupils (STOP) tidak memiliki pengaruh yang signifikan terhadap kontrol diri siswa SMP.

\section{Diskusi}

Berdasarkan pada hasil uji hipotesis yang telah dilakukan, diketahui bahwa hipotesis ditolak, artinya tidak adanya perbedaan skor kontrol diri yang signifikan antara pretest dan posttest pada subjek penelitian. Berikut adalah rangkuman hasil pretest dan posttest penelitian. 
Hasil dari penelitian ini menunjukkan ada tiga orang subjek yang mengalami kenaikan skor kontrol diri. Ketiga orang tersebut terdiri dari dua orang mengalami kenaikan skor kontrol diri sebanyak 1 poin dan satu orang mengalami kenaikan skor kontrol diri sebanyak 2 poin. Empat orang tidak mengalami perubahan pada skor kontrol diri pretest dan posttest. Selain itu, ada satu orang yang mengalami penurunan skor kontrol diri sebesar 1 poin. Data tersebut cukup membuktikan bahwa perlakuan yang diberikan, dalam hal ini Pelatihan Self-control for Pupils (STOP) tidak memberikan pengaruh yang signifikan terhadap skor kontrol diri peserta. Hal ini dikarenakan hanya tiga orang mengalami peningkatan, yang artinya kurang dari setengah dari jumlah subjek keseluruhan. Selain itu, justru ada satu orang yang mengalami penurunan skor. Pengaruh yang signifikan dapat diperoleh apabila keseluruhan subjek mengalami perubahan skor.

Dari hasil evaluasi pelatihan oleh delapan subjek penelitian, didapatkan evaluasi bahwa meskipun pelaksanaan pelatihan berjalan dengan lancar, namun durasi pelatihan kurang lama sehingga masih terdapat materi pelatihan yang belum dapat dipahami oleh subjek. Waktu pelaksanaan pelatihan ini memang dilakukan penyesuaian karena berkaitan dengan izin yang diberikan oleh pihak sekolah. Pelatihan ini sebenarnya akan dilakukan dalam dua kali pertemuan, yang terdiri dari satu kali pertemuan dalam satu hari. Akan tetapi, pada pelaksanaannya pelatihan ini dilakukan dalam waktu satu kali pertemuan dengan durasi tiga jam. Hal itulah yang menjadi salah satu penyebab adanya peserta yang belum dapat memahami materi pelatihan karena keterbatasan waktu dan juga trainer tidak dapat melakukan penjelasan lebih lanjut untuk mengetahui pemahaman masing-masing subjek.

Kontrol diri memang dapat ditingkatkan melalui pelatihan. Akan tetapi, tidak mudah dalam melakukannya. Hal-hal yang sudah menjadi kebiasaan kita sehari-hari merupakan hasil dari pembelajaran sejak kita lahir (TuckerLadd, 2011). Konsep tersebut juga berlaku bagi dalam penelitian ini. Eksperimen yang dilakukan berupa pemberian pelatihan dilakukan selama kurang lebih tiga jam. Hasil yang diharapkan adalah adanya pengaruh yang signifikan terhadap skor kontrol diri subjek penelitian. Dengan kata lain, diharapkan pelatihan yang diberikan dapat meningkatkan kemampuan kontrol diri subjek penelitian, terutama dalam hal pengendalian emosi dan juga perilaku. Tujuannya adalah adanya perubahan perilaku pada subjek penelitian.

Analisis data pretest dan posttest menunjukkan hasil bahwa pelatihan yang diberikan tidak berpengaruh secara signifikan terhadap perubahan skor kontrol diri subjek penelitian. Dengan kata lain, tidak ada perubahan perilaku secara menyeluruh pada subjek penelitian. Hal ini dapat dijelaskan melalui konsep yang disampaikan oleh Tucker-Ladd (2011) bahwa perubahan perilaku merupakan hasil dari proses pembelajaran yang kompleks. Subjek penelitian tidak dapat langsung merasakan pengaruhnya untuk saat ini, sebagaimana perubahan perilaku berupa kontrol diri dapat langsung meningkat melalui pelatihan selama tiga jam. Meskipun demikian, setiap proses 
pembelajaran sangat berarti bagi sebuah perubahan untuk menjadi lebih baik.

Salah satu model penguatan kontrol diri menyatakan bahwa kontrol diri bereaksi seperti otot pada tubuh. Kontrol diri akan menjadi lemah apabila jarang digunakan. Sebaliknya, apabila sering digunakan maka kontrol diri akan semakin kuat. Oleh karena itu, penggunaan kontrol diri yang berulangulang dapat meningkatkan kemampuan seseorang dalam mengendalikan dirinya (Gailliot \& Baumeister, 2007). Hal tersebut dapat kita implikasikan dalam penelitian ini. Peneliti menyetujui bahwa dampak atau pengaruh dari suatu pelatihan akan lebih terlihat dengan jelas apabila dilakukan secara berkelanjutan. Hal ini dikarenakan peneliti dapat melihat perkembangan dari perubahan perilaku yang diinginkan pada subjek penelitian.

Pelatihan dalam penelitian eksperimen ini dilakukan dalam satu kali pertemuan dengan durasi kurang lebih tiga jam. Hal ini dapat menjadi penyebab tidak munculnya perubahan perilaku yang diharapkan terjadi pada eksperimen ini. Satu kali pelaksanaan pelatihan dirasa belum mampu untuk dapat melihat terjadinya perubahan perilaku sesuai dengan tujuan penelitian. Hal inilah yang menjadi salah satu penyebab tidak signifikannya pengaruh perlakuan yang diberikan terhadap skor kontrol diri subjek penelitian.

Posttest dan evaluasi dalam penelitian ini dilakukan satu minggu sejak pelaksaan pelatihan. Subjek juga tidak diberikan follow up sampai dengan pemberian posttest. Subjek penelitian diminta untuk mengisi kembali skala kontrol diri sebagai instrumen posttest. Hasil posttest tersebut selanjutnya dianalisis bersama dengan hasil pretest dan ternyata tidak terdapat perubahan yang signifikan pada skor kontrol diri subjek penelitian. Salah satu hal yang dapat berpengaruh terhadap hasil tersebut adalah adanya pengaruh lingkungan. Perilaku yang kita lakukan banyak dipengaruhi oleh lingkungan (Tucker-Ladd, 2011). Selama satu minggu tersebut, peneliti tidak mengetahui apa saja yang telah terjadi pada subjek penelitian. Oleh karena itu, kemungkinan adanya pengaruh lingkungan terhadap subjek penelitian tetap dapat terjadi.

Validasi isi modul pelatihan STOP memiliki nilai koefisien Aiken's $V$ yang bergerak dari $0.6-0.95$. Hasil tersebut dapat diartikan bahwa modul pelatihan STOP memiliki validitas isi yang baik. Meskipun demikian, hasil pengolahan data pelaksanaan penelitian menunjukkan bahwa pelatihan yang diberikan tidak berpengaruh secara signifikan terhadap kontrol diri siswa SMP. Dengan demikian, dapat ditarik kesimpulan bahwa validitas isi modul pelatihan yang baik/tinggi belum tentu dapat digunakan untuk meningkatkan kontrol diri peserta pelatihan. Hal ini berkaitan dengan proses professional judgment. Professional judgment tersebut bersifat judgemental dan berdasar analisis rasional masing-masing expert (Azwar, 2012). Oleh karena itu, hasil yang tidak signifikan dapat diperoleh pada saat uji empirik di lapangan untuk mengetahui pengaruh pelatihan terhadap kontrol diri peserta pelatihan.

Penelitian ini memiliki beberapa keterbatasan dalam pelaksanaannya. Penelitian ini dilakukan pada subjek yang pernah terlibat dalam permasalahan di sekolah. Pelatihan kontrol diri diharapkan mampu meningkatkan kemampuan kontrol diri subjek sehingga dapat 
mengurangi kemungkinan munculnya permasalahan di sekolah. Akan tetapi, tidak semua subjek merupakan siswa yang pernah terlibat dalam permasalahan di sekolah. Hal ini dikarenakan dalam pencarian subjek juga berdasarkan kesukarelaannya untuk menjadi subjek penelitian.

Pelaksanaan pelatihan juga dilakukan selama satu kali pertemuan saja dengan durasi yang tidak terlalu lama. Hal ini dapat berdampak pada pengaruh pelatihan tersebut terhadap hasil dari penelitian. Posttest dan evaluasi pelatihan dilakukan satu minggu setelah pelaksanaan pelatihan, tanpa disertai follow up dalam satu minggu itu. Hal tersebut dapat memunculkan adanya pengaruh dari lingkungan yang berdampak pada hasil posttest. Selain itu, kegiatan di dalam pelatihan masih berupa kegiatan umum yang masing-masing mewakili aspek dari kontrol diri, yaitu emotion expression dan adaptive behavior. Dengan demikian, hanya ada dua kegiatan utama saja yang ada pada pelatihan ini. Hal ini ternyata belum mampu mengarahkan subjek pada perilaku yang spesifik terkait penjabaran dari masingmasing aspek dalam kontrol diri.

\section{Kesimpulan}

Penelitian dilakukan dengan melibatkan delapan orang subjek penelitian yang menjadi kelompok eksperimen. Delapan subjek penelitian tersebut mendapatkan perlakuan berupa pelatihan Self-control for Pupils (STOP). Hasil yang didapatkan dalam penelitian ini adalah pelatihan Selfcontrol for Pupils (STOP) tidak berpengaruh secara signifikan terhadap perubahan skor kontrol diri siswa SMP $(t=-1,158 ; p=0,285$; $\mathrm{p}>$ 0.05). Penelitian ini menunjukkan bahwa kontrol diri dapat ditingkatkan melalui pelatihan. Akan tetapi, tidak mudah dalam melakukannya. Hal tersebut merupakan hasil dari proses pembelajaran yang kompleks dan juga berkesinambungan. Seseorang sebaiknya senantiasa berlatih untuk mengendalikan dirinya. Hal ini dikarenakan betapa pentingnya kontrol diri dalam menjalani kehidupan.

\section{Saran}

Peneliti juga mempunyai saran untuk penelitian selanjutnya, yaitu melakukan studi mendalam pada variabel kontrol diri serta penerapannya dalam pelatihan agar kegiatan yang ada di dalam pelatihan mampu meningkatkan kemampuan kontrol diri peserta pelatihan. Penentuan subjek dalam penelitian eksperimen sebaiknya melalui proses screening pada populasi subjek penelitian untuk mengetahui kondisi dan karakteristik kemampuan kontrol diri calon subjek penelitian. Hal ini dilakukan untuk dapat memilih subjek yang sesuai dengan tujuan penelitian. Selain itu, peneliti selanjutnya perlu empertimbangkan durasi, follow up dan intensitas pelaksanaan perlakuan kepada subjek penelitian berupa serangkaian proses pelatihan. Hal ini ditujukan untuk memperoleh hasil penelitian yang lebih lengkap.

\section{Daftar Pustaka}

Azwar, S. (2012). Reliabilitas dan validitas. Yogyakarta: Pustaka Pelajar.

Berger, A. (2011). Self-regulation: Brain, cognition, and development. Washington: American Psychological Association. 
Casey, B. J., \& Caudle, K. (2013). The teenage brain: Self control. Current Directions in Psychological Science, 22, 82-87. doi: 10.1177/09637214 $\underline{13480170}$

Christensen, L. B. (2004). Experimental methodology (9th ed.). Boston: Pearson.

Etikan, I., Musa, S. A., \& Alkassim, R. S. (2016). Comparison of convenience sampling and purposive sampling. American Journal of Theoretical and Applied Statistics, 5(1), 1-4. doi: 10.11648/j.ajtas.20160501.11

Gailliot, M. T., \& Baumeister, R. F. (2007). Self-regulation and sexual restraint: Dispositionally and temporarily poor self-regulatory abilities contribute to failures at restraining sexual behavior. Personality and Social Psychology Bulletin, 33(2), 143-159. doi: 10.1177/0146167206293472

Janah, M. R. (2014). Pengaruh pelatihan kontrol diri dengan menggunakan metode tehnik gerakan mengontrol perilaku merokok untuk mengurangi perilaku merokok pada siswa SMK Harapan Kartasura. Talenta Psikologi, 3(1), 79-100.

Kumara, A., Wimbarti, S., Susetyo, Y. F., \& Widhiarso, W. (2016). Epidemiologi kesehatan mental anak dan remaja berbasis sekolah. Yogyakarta: Fakultas Psikologi Universitas Gadjah Mada.

Nindya, P. N., \& Margaretha, R. N. (2012). Hubungan antara kekerasan emosional pada anak terhadap kecenderungan kenakalan remaja. Jurnal Psikologi Klinis dan Kesehatan Mental, 1(3), 124-132. Diunduh dari http://www.journal.unair.ac.i

d/download-fullpapersjpkk17d35e73b52full.pdf

Putri, J. D. (2014). Efektivitas paket pelatihan kontrol diri dalam perilaku berpacaran siswa kelas VIII. Skripsi (tidak dipublikasikan). Malang: Universitas Negeri Malang

Rohmadani, Z. V. (2011). Efektivitas pelatihan kontrol diri (self control training) dalam menurunkan kecenderungan kenakalan remaja di Madrasah Aliyah Negeri II Yogyakarta. Skripsi (tidak dipublikasikan). Yogyakarta: UIN Sunan Kalijaga

Russel, J. D., \& Johanningsmeier, K. A. (1981). Improving competence through modular instruction. Iowa: Kendall/Hunt Publishing Company.

Santrock, J. W. (2011). Life-span development 13th edition. New York: McGrawHill.

Schunk, D. H. (2005). Self-regulated learning: The educational legacy of Paul R. Pintrich. Educational Psychologist, 40(2), 85-94. doi: 10.1207/s15326985ep4002_3

Spear, L. (2007). The developing brain and adolescent-typical behavior patterns: An evolutionary approach. In D. Romer, \& E. F. Walker, Adolescent psychopatology and the developing brain: Integrating brain and prevention science (pp. 930). New York: Oxford University Press.

Supratiknya, A. (2011). Merancang program dan modul psikoedukasi. Yogyakarta: Universitas Sanata Dharma. 
Tarullo, A. R., Obradovic, J., \& Gunnar, M. R. (2009). Self-control and the developing brain. Zero to Three, 29(3), 31-37.

Tucker-Ladd, C. E. (2011). Psychological self-help. Clayton Tucker-Ladd. Diunduh dari https://www. psychologicalselfhelp.org/

Utami, D. P. (2012). Masalah mental dan emosional pada siswa SMP kelas akselerasi dan reguler. Jurnal Media Medika Muda, 1-13
Warry, C. J., Remington, B., \& SonugaBarke, E. J. (1999). When more means less: Factors affecting human self-control in a local versus global choice paradigm. Learning and Motivation, 30, 53-73. doi: $\underline{10.1006 / 1 m o t .1998 .1018}$ 